\title{
Opportunities to Elevate Levels of Curcumin in Curcuma xanthorrhiza
}

\section{Plants}

Authors

Afiliation
Pertamawati

Center for Pharmaceutical and Medicine Technology - LAPTIAB - BPPT

\section{Keyword \\ - C.xanthorrhiza \\ $\rightarrow$ callus culture \\ $\rightarrow$ curcuminoids}

Received 7 September 2015 Revised 7 Februari 2017 Accepted 25 Januari 2018

*Corresponding author Pertamawati PUSPIPTEK Area - Serpong Banten pertamawatikartakusumah@g mail.com

\section{ABSTRACT}

Production of curcuminoids from Curcuma xanthorrhiza using conventional cultivation technique requires a very long time from planting to harvesting process. The use of biotechnology known as the callus culture is expected to help this problem. An experiment was conducted with the explant of curcuma leaves which are cultured in basic media of Murashige \& Skoog (MS) with addition of growing substances Phenilalanine (2-amino-3-fenil-propanoat acid/ $\mathrm{C}_{9} \mathrm{H}_{11} \mathrm{NO}_{2}$ ) with a concentration of 2, 4 and $8 \mathrm{mg} / \mathrm{L}$ and Sodium Acetate $\left(\mathrm{CH}_{3} \mathrm{COONa}\right)$ with concentration of 0.2 and $4 \mathrm{mg} / \mathrm{L}$. Experiments done with random design with 3 times replication. The results showed that addition of Phenilalanine at a concentration of $4 \mathrm{mg} / \mathrm{L}$ produced curcuminoids namely curcumin $0.8861 \%$ and desmethoxycurcumin $0.3307 \%$, while the addition of sodium acetate $2 \mathrm{mg} / \mathrm{L}$ was able to induce the formation of curcuminoids namely curcumin $0.7514 \%$ and desmethoxycurcumin $0.3898 \%$. It is suggested that further research with a callus induction technology in tissue culture need to be conducted for producing curcumin in an industrial scale.

\section{INTRODUCTION}

Temulawak (Curcuma xanthorrhiza Roxb.) is an Indonesian native and widely used as medicines, food, colorings in raw material industry (cosmetics) and rated fresh of food / drink (Indrayanto 1987; Dalimartha 2000). Rukmana (1995) said that temulawak rhizome contains starch fraction, curcominoid and essential oils (3-11\%). The curcuminoid fraction consists of curcumin and desmethoxycurcumin (Afifah et al., 2005; Dalimartha 2000). Curcuminoid is one of the secondary metabolite which have the activities as antihepatotoxic, antiinflamasi and antioxidant (Tonnesen 1986). Most of secondary metabolite including curcuminoid obtained can be commercially isolated from plants (Cahyono 1998).

The production of secondary metabolite compound in the plant tissue culture is highly influenced by several factors, among other genetic factors and the media

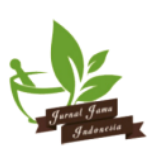


growing also substance plants hormone (Street 1977; Hendaryono and Wijayni 1994; Untung and Fatimah, 2003). Auxin known as plant hormone that induces the capability of callus formation (Tomes et al. 1982; Untung and Fatimah 2003). Precursor is a compound that plays role in the secondary metabolite biosynthesis, namely by stimulating the formation of a secondary metabolite in plants.

A secondary metabolite in plants is available only in small quantities. So the addition of a precursor in culture media capable of stimulating the formation of secondary metabolite. Based on the theory, research on the effect of the precursor provision on curcuminoids formation in temulawak callus in MS Media.

\section{METHODS}

Plant material is callus, rhizome and shoots of temulawak (Curcoma xanthorrhiza Roxb.). The basic media used is Murashige \& Skoog (MS) with the addition of plant hormone Naphthalene Acetic Acid (NAA) and Furfuril Amino Purine (FAP) with the same concentration $(3: 3 \mathrm{mg} / \mathrm{l})$. A precursor of Phenilalanine and Sodium Acetate given in successive amount of 0 $\mathrm{mg} / \mathrm{l} ; 2 \mathrm{mg} / \mathrm{l}$ and $4 \mathrm{mg} / \mathrm{l}$.

\section{Reagent}

The reagent a chemicals that used during this study were Dithane 430F, etanol 70\%, Bayclin ( $\mathrm{Na}$ hypocloride), Tween 80 and aquadest sterile, also used chemicals for analysis o curcuminoid in TLC (Thin Layer Chromatography), methanol, ethanol 96\%, acetic acid glacial, chloroform, hexane, ethyl acetate, silica gel plate GF254 and curcuminoid standard. Material for analysis was $\mathrm{NaOH} 5 \%$ and concentrated sulfuric acid : ethanol $96 \%$ with comparison 1:1.

\section{Instrument}

Culture bottle and glassware, pipet drops, syringe, $\mathrm{pH}$ indicator stick, aluminium foil, autoclave, pinzet, scapel, LAF petri dish, petri dish, UV illuminator, kit densitometer (TLC scanner cs-930).

\section{Observation}

The parameters of observation include time of the explant forms a callus, done by means of noted day of how every explant that cultured form a callus. The percentage of a callus growth by counting the number of explant that succeed forming callus divided by the total number of explant planted, and harvesting of callus, done after the formed callus ready for harvesting, indicated by explant that have been overgrown with a callus

\section{Curcuminoid analysis}

The callus, shoots and rhizome were dried in an oven at temperatures of roughly $50^{\circ} \mathrm{C}$ then mashed. Dry powder mixed with methanol (p.a) at a ratio of 1:10 (b/v) shaked at a speed $80 \mathrm{rpm}$ for 24 hours. Filtrate produced is collected the methanol volatilized in order to obtain the dry methanolic extract. Methanolic extracts obtained, then weighed and is dissolved in $10 \mathrm{mls}$ of methanol (p.a). $50 \mathrm{mg}$ of curcominoid pollen standard was then added to $10 \mathrm{ml}$ omethanol (p.a) to obtain curcuminoid standard 5000 $\mathrm{mg} / \mathrm{l}$. Then pipeted the solution as much as $1 \mathrm{ml}$ plus methanol (p.a) into squash measures of $100 \mathrm{mls}$ of a solution until reached of $50 \mathrm{mg} / \mathrm{l}$ stock solution. Then 1 $\mathrm{ml}$ of solution is added to $100 \mathrm{ml}$ of methanol to obtain $50 \mathrm{mg} / \mathrm{l}$ stock solution.

\section{Qualitative analysis}

The qualitative analysis was conducted using color reaction. The extract was added with $\mathrm{NaOH} 95 \%$ and curcuminoid was shown with red and reddish orange. (Wagner 1985). The palette used to be silica gel GF254 (stationary phase). Solution for curcuminoid standard, callus extract, shoots and rhizome of temulawak was spoted each as much as $1 \mathrm{ul}$ on the plate using a micropipet at a distance of $1.5 \mathrm{~cm}$ from bottom, left and right side plates. The distance between spots are also $1,5 \mathrm{~cm}$. During the spotting, the stain on the plate are air dried, then the plates were developed in chromatography vessels that is saturated with a developing solution chloroform : ethanol 96\% ; acetic acid glacial (94:5:1) as phase motion (Wagner et al. 1984).

Eluent for chromatography was also using ethanol $96 \%: \mathrm{CHCl}_{3}$ (7:3) and hexane : Ethyl acetate (1:1) (Wagner et al. 1984). Plate left in order to continue with motion solution following the developers spot. The development was stopped after reaching a compromise distance of $7.5 \mathrm{~cm}$. Plates were observed under UV light $254 \mathrm{~nm}$ and patches are identified by comparing the color and value of hRf callus, shoots and rhizome temulawak with hRf curcuminoid for comparison. A solution for developers with the best separation was then used for identification of all callus.

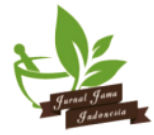




\section{Quantitative analysis}

The standard curve of curcuminoid made from standard solution with a concentration of $50 \mathrm{mg} / \mathrm{l}$, that spots as much as 1, 2, 4, 8 and $16 \mu$ in silica gel GF254. Then development in a developing is to provide the best solution for qualitative identification. The spot was analyzed using TLC densitometer, the broad area and heavy spot were put into linear based curve regression.

The determination of curcuminoid levels in callus extract with spotting $16 \mathrm{ul}$ of the solution then developed with a developing solution that gives best separation at the qualitative test. Spotting detected with a TLC densitometer tool. The results of widespread area detection put into the linear regression of curcuminoid curve. The chromatography test was done $3 \mathrm{t}$ replication using the similar phase developer and solution.

\section{RESULTS AND DISCUSSION}

Curcuma extract contains many phenol compounds, therefore optimal sterilization method is required. The best sterilization method is done by immersion into the following substances : Detergent for 5 minutes; Aquadest sterile for 10 minutes; Dithane $430 \mathrm{f}$ for 30 minutes; Bayclin $30 \%$ and Tween 80 for 10 minutes; Bayclin 15\% and Tween 80 For 5 minutes and Ethanol $70 \%$ for 1 minute.

\section{Procentage of the callus growth}

The determination of the callus growth by counting the number of explant that manage to form callus divided by the total explant planted multiplied by $100 \%$. The percentage success of culture, rhizome and shoots of temulawak is on Table 1 and Graph 1.

Table 1 The influence of the addition of the precursors to callus media grow of Curcuma xanthorrhiza Roxb (\%)

\begin{tabular}{lcc}
\hline No. & The Precursor & Callus growth (\%) \\
\hline 1 & $\mathrm{MS}_{0}$ & 60 \\
2 & $\mathrm{PA}_{2} \mathrm{NA}_{0}$ & 60 \\
3 & $\mathrm{PA}_{4} \mathrm{NA}_{0}$ & 60 \\
4 & $\mathrm{PA}_{0} \mathrm{NA}_{2}$ & 40 \\
5 & $\mathrm{PA}_{2} \mathrm{NA}_{2}$ & 80 \\
6 & $\mathrm{PA}_{4} \mathrm{NA}_{2}$ & 40 \\
7 & $\mathrm{PA}_{0} \mathrm{NA}_{4}$ & 80 \\
8 & $\mathrm{PA}_{2} \mathrm{NA}_{2}$ & 80 \\
9 & $\mathrm{PA}_{4} \mathrm{NA}_{4}$ & 80 \\
\hline
\end{tabular}

Information :

$\mathrm{MS}_{0} \quad$ : Medium MS without addition of a hormone and precursor

$\mathrm{PA}_{2} \mathrm{NA}_{0} \quad$ : Medium MS with addition of Phenilalanin 2 $\mathrm{mg} / \mathrm{l}$ and Sodium Acetate $0 \mathrm{mg} / \mathrm{I}$

$\mathrm{PA}_{4} \mathrm{NA}_{0} \quad$ : Medium MS with addition of Phenilalanin 4 $\mathrm{mg} / \mathrm{l}$ and Sodium Acetate $0 \mathrm{mg} / \mathrm{l}$

$\mathrm{PA}_{0} \mathrm{NA}_{2}$ : Medium MS without addition of Phenilalanin and Sodium Acetate $2 \mathrm{mg} / \mathrm{l}$

$\mathrm{PA}_{2} \mathrm{NA}_{2}$ : Medium MS with addition of Phenilalanin 2 $\mathrm{mg} / \mathrm{l}$ and Sodium Acetate $2 \mathrm{mg} / \mathrm{l}$

$\mathrm{PA}_{4} \mathrm{NA}_{2} \quad$ : Medium MS with addition of Phenilalanin 4 $\mathrm{mg} / \mathrm{l}$ and Sodium Acetate $2 \mathrm{mg} / \mathrm{l}$

$\mathrm{PA}_{0} \mathrm{NA}_{4}$ : Medium MS without addition of Phenilalanin and Sodium Acetate $4 \mathrm{mg} / \mathrm{l}$

$\mathrm{PA}_{2} \mathrm{NA}_{4}$ : Medium MS with addition of Phenilalanin 2 $\mathrm{mg} / \mathrm{l}$ and Sodium Acetate $4 \mathrm{mg} / \mathrm{l}$

$\mathrm{PA}_{4} \mathrm{NA}_{4} \quad$ : Medium MS with addition of Phenilalanin 4 $\mathrm{mg} / \mathrm{l}$ and Sodium Acetate $4 \mathrm{mg} / \mathrm{l}$

\section{Callus Growth (\%)}

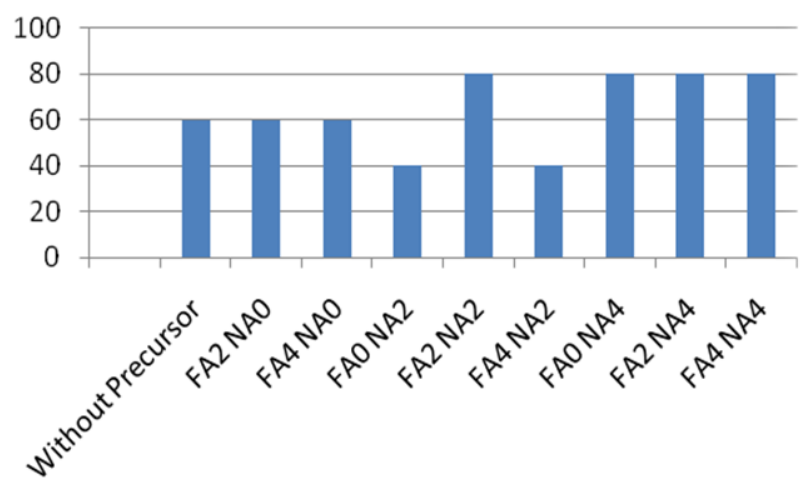

Graph 1 The Influence of Precursor Addition to Growing Media Against Procentase Temulawak Callus (\%)

\section{The information of Graph 1 equal to the information} of Table 1

Growth of a good explant is characterized by the incomplete occurrence of browning, and contaminated by fungi or bacteria either on explant and medium. The percentage success of temulawak callus growth was not influenced by the provision of precursor treatment. This can be seen in Table 1, in the media is MS without the addition of precursor (control) the callus growth is almost similar to the media with the addition of a precursor. Even media MS without the addition of a

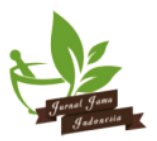


precursor shows callus growth better if compared with the addition of $\mathrm{PA}_{0} \mathrm{NA}_{2}$ and $\mathrm{PA}_{4} \mathrm{NA}_{2}$.

\section{The explant time to form a callus}

The formation of callus started with the establishment of a cluster around a wedge on the clear colorless explant. The time of the formation of callus shown on a Table 2 and Graph 2.

Table 2 The influence of the addition of the precursor to media growing against time the formation of callus (day)

\begin{tabular}{ccc} 
No. & The Precursor & $\begin{array}{c}\text { The formation of } \\
\text { Callus (days) }\end{array}$ \\
\hline 1 & $\mathrm{MS}_{0}$ & 28.5 \\
2 & $\mathrm{PA}_{2} \mathrm{NA}_{0}$ & 26.2 \\
3 & $\mathrm{PA}_{4} \mathrm{NA}_{0}$ & 26.4 \\
4 & $\mathrm{PA}_{0} \mathrm{NA}_{2}$ & 25.8 \\
5 & $\mathrm{PA}_{2} \mathrm{NA}_{2}$ & 24.9 \\
6 & $\mathrm{PA}_{4} \mathrm{NA}_{2}$ & 25.1 \\
7 & $\mathrm{PA}_{0} \mathrm{NA}_{4}$ & 26.5 \\
8 & $\mathrm{PA}_{2} \mathrm{NA}_{2}$ & 26.0 \\
9 & $\mathrm{PA}_{4} \mathrm{NA}_{4}$ & 26.0 \\
\hline
\end{tabular}

Callus Growth (Day)

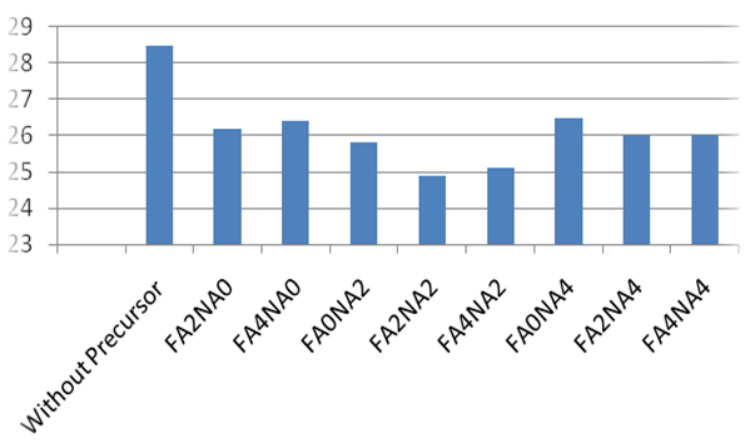

Graph 2 The Influence of the Addition of the Precursor to in a Media Growing Against the Time of Formation Calls (days).

The information of Table 2 equal to the information of Table 1

In Graph 2 it can be seen that the provision of precursor tends to accelerate callus formation. The provision of a precursor $\mathrm{PA}_{2} \mathrm{NA}_{2}$ produces the best effect on the formation of temulawak callus with the fastest time of 24.9 days.

\section{Harvesting callus}

Harvesting callus is conducted when the colorless transparent whole clustered around explant was established. Harvesting callus is done after a callus was about 8 weeks. The results of the weighing of callus wer in Table 3.

Tabel 3 The Heavy Temulawak Callus

\begin{tabular}{ccc}
\hline \multirow{2}{*}{ Treatment } & \multicolumn{2}{c}{ Weight of Callus (gram) } \\
\cline { 2 - 3 } & Fresh & Dry \\
\hline $\mathrm{MS}_{0}$ & 3.98 & 0.343 \\
Controle & 0.972 & 0.096 \\
$\mathrm{FA}_{2} \mathrm{NA}_{0}$ & 1.09 & 0.107 \\
$\mathrm{FA}_{4} \mathrm{NA}_{0}$ & 0.72 & 0.067 \\
$\mathrm{FA}_{0} \mathrm{NA}_{2}$ & 0.55 & 0.053 \\
$\mathrm{FA}_{2} \mathrm{NA}_{2}$ & 1.68 & 0.164 \\
$\mathrm{FA}_{4} \mathrm{NA}_{2}$ & 0.23 & 0.023 \\
$\mathrm{FA}_{0} \mathrm{NA}_{4}$ & 1.65 & 0.163 \\
$\mathrm{FA}_{2} \mathrm{NA}_{4}$ & 1.83 & 0.18 \\
$\mathrm{FA}_{4} \mathrm{NA}_{4}$ & 1.89 & 0.191 \\
\hline
\end{tabular}

The provision of a precursort has the effect of a fresh the callus weight. The callus in medium without the addition of precursors (MSO) have greater weight than any other medium The smallest weight of callus is in medium with the addition of Phenilalanin $4 \mathrm{mg} / \mathrm{l}$ and Sodium Acetate $2 \mathrm{mg} / \mathrm{l}$.

\section{The qualitative analysis of curcuminoid}

Preliminary test was conducted to ensure curcuminoid is in callus. shoots and rhizome of temulawak and was extracted with methanol. Data weighting of a rhizome and the shoot can be seen in Table 4

Table 4 A weighing of Temulawak Rhizome and Shoots

\begin{tabular}{lcc}
\hline \multirow{2}{*}{ Kinds } & \multicolumn{2}{c}{ Weight (gram) } \\
\cline { 2 - 3 } & Fresh & Dry \\
\hline Rhizome of Temulawak & 20.132 & 1.4 \\
Shoot of Temulawak & 10.616 & 1.4 \\
\hline
\end{tabular}

Analysis of curcuminoid in temulawak rhizome and shoots is necessary to compare the curcuminoid contained in a callus. All materials in Table 1 and Table 3 were extracted with methanol. Qualitative test was done through the reaction of colour and TLC (Thin Layer Chromatopgaphy). The results of the colour test 
of curcuminoid performed on the extract callus. rhizome and shoots of temulawak.

Based on the colour reaction indicates that in the shoots. rhizome and callus of temulawak study containing curcuminoid (data are not shown). TLC analysis was conducted on all callus that have growth and maximum results.

The first step of TLC was conducted on a standard curve. The callus. rhizome and shoots of temulawak was tested by using silica gel GF254 and developed with 3 types of eluent. namely :

- $\mathrm{CHCl}_{3}$ : ethanol 96\% : Acetic Acid (94:5:1)

- Ethanol 96\%: $\mathrm{CHCl}_{3}$ (7:3)

- Hexane : Ethyl Acetate (1:1)

The use of 3 solution different developer is intended to clarify the identification. Chromatogram of TLC results seen in Table 5 .

Table 5 Result at phase Silica Gel GF254 with a solution developer $\mathrm{a}$. b and c

\begin{tabular}{|c|c|c|}
\hline $\begin{array}{l}\text { Developer } \\
\text { solution }\end{array}$ & Spotting & $\begin{array}{l}\text { hRf } \\
\text { value }\end{array}$ \\
\hline \multirow{3}{*}{$\begin{array}{l}\mathrm{CHCl}_{3}: \text { Ethanol } 96 \% \\
: \text { glacial Acetic Acid } \\
(94: 5: 1)\end{array}$} & B1 : Spotting I (Curcumin) & 60 \\
\hline & $\begin{array}{l}\text { B2 : Spotting } \\
\text { (Desmethoxycurcumin) }\end{array}$ & 50 \\
\hline & $\begin{array}{l}\text { B3 : Spotting III } \\
\text { (Bisdesmethoxycurcumin) }\end{array}$ & 40 \\
\hline $\begin{array}{l}\text { Ethanol } 96 \%: \mathrm{CHCl}_{3} \\
(7: 3)\end{array}$ & 1 spotting & 90 \\
\hline $\begin{array}{l}\text { Hexana : } \quad \text { Ethyl } \\
\text { Acetat (1:1) }\end{array}$ & 1 spotting & 50 \\
\hline
\end{tabular}

Table 5 shows the results of the separation using the three types of developing solution. The best separation is indicated by developing solutions (1) the $\mathrm{CHCl}_{3}$ : Ethanol 96\% : Acetic Acid glacial (94:5:1). because this developing solution is capable of separating components curcuminoid. Curcuminoid standard shows the separation that produces 3 spot because of component curcuminoid standard used consists of curcumin. desmethoxycurcumin and bisdesmethoxycurcumin. The separation of spotting on a callus. rhizome and shoots of temulawak only produces 2 spotts indicating components of curcumin and desmethoxycurcumin.

Result on developing solution of Ethanol $96 \%: \mathrm{CHCl}_{3}$ (7:3) and Hexane : Ethyl Acetate (1:1) does not show the separation of curcuminoid components because only produce 1 patches. The results indicating separation on the curcuminoid in a callus. rhizome and shoots of temulawak. because having $h R f$ value equal to the hRf value of curcuminoid standard.

Commonness by virtue of polar characteristic of a curcuminoid component of a developing solution of the $\mathrm{CHCl}_{3}$ : Ethanol 96\%: glacial Acetic Acid (94:5:1). show that blots appear on hRf 50 is desmethoxycurcumin and of wheals that appears at hRf 60 is curcumin. Spotting bisdesmethoxycurcumine on curcuminoid standard appear on hRf 40 and was not found in callus. rhizomes and shoots of temulawak. This is in accordance with that reported by Stahl (1985) that curcuminoid on a callus and rhizomes of temulawak containing only curcumin and desmethoxycurcumine

Further analysis was conducted to all callus using a developing solution of the $\mathrm{CHCl}_{3}$ : Ethanol $96 \%$ : glacial Acetic Acid (94:5:1) that showed the best results of separation. Further analysis indicated by TLC data at phase of the silica gel GF254 with a developer solution of the $\mathrm{CHCl}_{3}$ : Ethanol 96\% : glacial Acetic Acid (94:5:1) under the UV $254 \mathrm{~nm}$ and $366 \mathrm{~nm}$. The results of testing show the total sample with $16 \mu \mathrm{l}$ spotting produces yellow spotting visually. brownish yellow on UV $254 \mathrm{~nm}$ and brown on UV $366 \mathrm{~nm}$. The test results showed that all callus examined contains compounds like curcuminoid on rhizome and shoots of temulawak. this can be seen from the same of spot colour with standard curcuminoid. the colour of spotts and hRf value.

The first step of TLC was conducted on a standard curve. One callus, rhizome and shoots of temulawak was tested by using phase of silica gel GF254 and developed with 3 types of developing solution, namely :

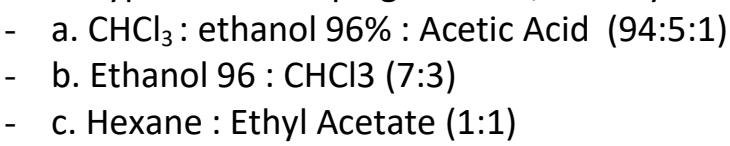

The use of 3 solution different developer is intended to clarify the identification. Chromatogram of TLC results seen in Figure 1.

Chromatogram profile in Figure 1 that shows the results of the separation using the three types of developing solution. The best separation is indicated by developing solution (1) the $\mathrm{CHCl}_{3}$ : Ethanol $96 \%$ : glacial Acetic Acid glacial (94:5:1), because this developing solution is capable of separating components curcuminoid. Curcuminoid standard shows the separation that produces 3 paches because of component curcuminoid standard used consists of curcumin, desmetoxicurcumin and 


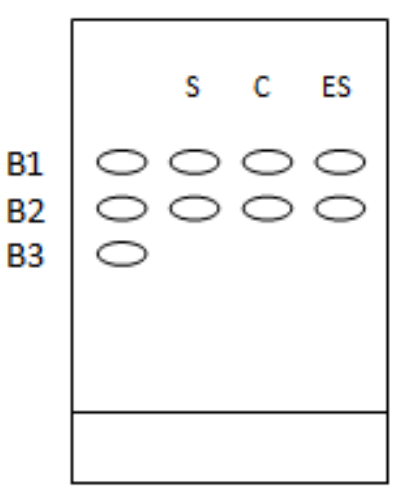

(a)

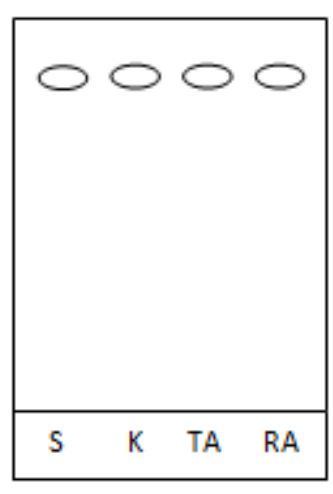

(b)
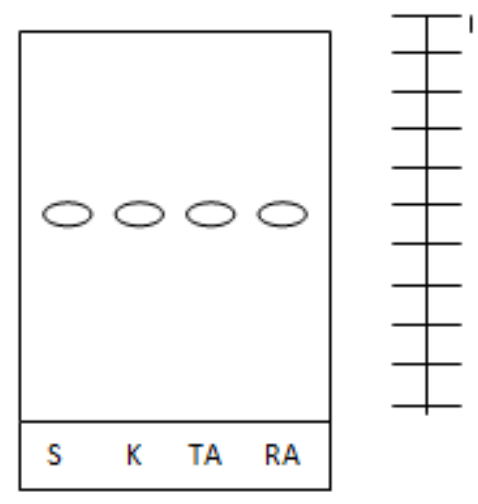

100

(c)

Figure 1. Chromatogram at phase Silica Gel GF254with a solution developer $a, b$ and c

\author{
Information : \\ S : Curcuminois extract standard \\ C : Extract of rhizome callus temulawak \\ ES : Extractof shoots temulawak \\ ER : Extract of rhizome temulawak \\ B1 : Spotting I (Curcumin) \\ B2 : Spotting II (Desmetoxicurcumin) \\ B3 : Spotting III (Bisdesmetoxicurcumin) \\ (a) : Developer solution $\mathrm{CHCl}_{3}$ : Ethanol 96\% : glacial Acetic Acid (94:5:1) \\ (b) : Developer solution Ethanol $96 \%: \mathrm{CHCl}_{3}(7 ; 3)$ \\ (c) : Developer solution Hexana : Ethyl Acetat (1:1)
}

bisdesmetoxicurcumin. The separation of spotting on a callus, rhizome and shoots of temulawak only produces 2 patches indicating components of curcumin and desmetoxycurcumin.

Chromatogram on developing solution of Ethanol 96\% : $\mathrm{CHCl}_{3}$ (7:3) and Hexane : Ethyl Acetate (1:1) does not show the separation of curcuminoid components because only produce 1 patches. The results indicating separation on the curcuminoid in a callus, rhizome and shoots of temulawak, because having hRf value equal to the $h R f$ value of curcuminoid standard.

Commonness by virtue of polar characteristic of curcuminoid component on a developing solution of the $\mathrm{CHCl}_{3}$ : Ethanol 96\% : glacial Acetic Acid (94:5:1), show that blots appear on hRf 50 is desmetoxicurcumin and of wheals that appears at hRf 60 is curcumin. Spotting bisdesmetoxycurcumine on curcuminoid standard appear on hRf 40 and was not founding in callus, rhizomes and shoots of temulawak. This is in accordance with that reportedby Stahl (1985) that curcuminoid on a callus and rhizomes of temulawak containing only curcumin and desmetoxycurcumine

Further analysis was conducted to all callus using a developing solution of the $\mathrm{CHCl}_{3}$ : Ethanol $96 \%$ : glacial Acetic Acid (94:5:1) that showed the best results of separation. Further analysis indicated by TLC data at phase of the silica gel GF254 with a developer solution of the $\mathrm{CHCl}_{3}$ : Ethanol 96\% : glacial Acetic Acid (94:5:1) under the UV $254 \mathrm{~nm}$ and $366 \mathrm{~nm}$. The results of testing shows the total sample with $16 \mu$ spotting produces yellow spotting visually, brownish yellow on UV $254 \mathrm{~nm}$ and brown on UV $366 \mathrm{~nm}$.

The test results showed that all callus examined contains compounds like curcuminoid on rhizome and shoots of temulawak, this can be seen from the same of spot colour with standard curcuminoid, the colour of patches and hRf value.

The third chromatogram profile producing 2 spotts (Table 6). Despite the hRf is a little different. so based on the results of the early identification (Figure 1 ) the

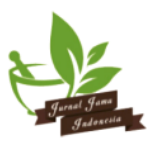


first spotting is curcumin and the second one is desmethoxycurcumin (Stahl. 1985).

Table 6 The result of callus. shoots and rhizome extract of temulawak on phase silica gel GF254

\begin{tabular}{llc}
\hline $\begin{array}{c}\text { Developer } \\
\text { solution }\end{array}$ & \multicolumn{1}{c}{ Spotting } & $\begin{array}{c}\text { hRf } \\
\text { value }\end{array}$ \\
\hline $\mathrm{CHCl}_{3}:$ Ethanol & B1 : Spotting 1 & 50 \\
$96 \%:$ glacial & (Curcumin) & \\
Acetic Acid & B2 : Spotting 2 & \\
(94:5:1) & (Desmethoxycurcumin) & \\
\hline
\end{tabular}

\section{The quantitative analysis of curcuminoid}

The curcuminoid standard solution as much as 1.2 . 4. 8 and $16 \mu \mathrm{L}$ spotted on a plate of silica gel GF254 was used for raw curve in a developing solution $\mathrm{CHCl}_{3}$ : ethanol 96\%: glacial Acetic Acid (94:5:1). The development was stopped after separation is perfectly complete. The results of the development showed 3 blots that are a component curcuminoid standard which consists of curcumin (spott 1. hRf 90). desmethoxycurcumin (spott 2. hRf 60) and bisdesmetoxycurcumin (spott 3. hRf 40).

Table 7 Result of quantitative analysis of curcuminoid

\begin{tabular}{llc}
\hline $\begin{array}{c}\text { Developer } \\
\text { solution }\end{array}$ & \multicolumn{1}{c}{ Spotting } & $\begin{array}{c}\text { hRf } \\
\text { value }\end{array}$ \\
\hline $\mathrm{CHCl}_{3}:$ & B1 : Curcumin & 90 \\
Ethanol 96\% & B2 : Desmethoxycurcumin & 60 \\
$:$ Glacial & B3: & 40 \\
acetic acid $=$ & Bisdesmethoxycurcumin & \\
$94: 5: 1$ & & \\
\hline
\end{tabular}

The determination of TLC curcuminoid levels on the plate. is followed by the determination of maximum wavelengths of curcuminoid. The results obtained that the maximum long wave curcuminoid is $368 \mathrm{~nm}$ Broad area and content of each spot from the wheals curcminoid standard use to make linear regression equation. The results of the calculation of the regression are as follow:

1. Test $I: Y=563.58+1835.77 X$

2. Test II $: Y=520.99+1592.26 \mathrm{X}$

The linear regression equation calculated are used to determine levels of curcuminoid of callus. shoots and rhizomes by inserting the value of the area that broadly obtained into an equation a line. Stahl (1985) said that curcuminoid callus and rhizome of temulawak produce 2 spotting on the chromatogram. while curcuminoid standard produce 3 patches. Based on that. the linear regression equation used for the calculation of the detection in broad areas on spotting 1 and 2.

\section{The determination of temulawak curcominoid level}

Curcuminoid level calculated from dry extract and dry callus. The result of curcuminoid calculation level (\%) shows that curcumin level of fresh callus in growing media with addition of Phenilalanin $4 \mathrm{mg} / \mathrm{l}$ is $0.8861 \%$ and desmethoxycurcumin is $0.3307 \%$. while the addition of Sodium Acetate $2 \mathrm{mg} / \mathrm{l}$ into growing media produce curcumin levels as many as $0.7514 \%$ and desmethoxycurcumin $0.3898 \%$. Curcumin levels and desmethoxycurcumin level were the highest in research. as written in Table 5.

Table 8 The level of curcumin and desmetoxycurcumin in fresh callus

\begin{tabular}{lcc}
\hline Precursor & $\begin{array}{c}\text { Level of } \\
\text { curcumin (\%) }\end{array}$ & $\begin{array}{c}\text { Level of } \\
\text { Desmetoxycurcumin } \\
\text { (\%) }\end{array}$ \\
\hline $\mathrm{MSO}$ & 0.270 & 0.233 \\
$\mathrm{FA}_{4} \mathrm{NA}_{0}$ & 0.8861 & 0.3307 \\
$\mathrm{FA}_{0} \mathrm{NA}_{2}$ & 0.75141 & 0.3898 \\
\hline
\end{tabular}

The research results show that in 8 weeks starting from the first day as the formation of callus. explant by the addition of a precursor in various concentrations produce curcuminoid in extract and callus with different level from their native bud of a plant.

In Table 8 it can be seen that the curcumin are much greater than the desmethoxycurcumin. The results of the study shows a callus in $\mathrm{MS}_{0}$ media have heavier weight than most other treatment (Table 1.) but curcuminoid level is least. The weight of the callus reflects a quality growth. A metabolite with the highest proportion allocate to growth is derived from primary metabolism. A callus with greater weight shows more accumulated primary metabolite but less secondary metabolite. It happens because the cell metabolism give higher priority to primary metabolite synthesis.

The level of curcuminoid temulawak rhizome (RA) was higher than the level of curcuminoid temulawak shoots (TA). because temulawak rhizome has experienced maximum growth. so that the synthesis of curcuminoid is more in temulawak rhizome. while

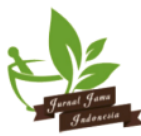


temulawak shoots just beginning the growth and the curcuminoid synthesized is still in small.

The level of curcuminoid extract higher than the level of curcuminoid of temulawak rhizome. shoots and callus. This shows that the level of curcuminoid extract not the same in curcuminoid of temulawak callus. rhizome and shoots.

The result showed that the addition of Phenilalanin in the medium without the addition of Sodium Acetate capable of inducing synthesis of curcuminoid. Although levels of curcuminoid smallest but it turn out the addition of Sodium Acetate without Phenilalanin also able to increase levels of temulawak curcuminoid. While Sodium Acetate has its effect on the synthesis of desmethoxycurcumin. the addition of Phenylalanin and Sodimum Acetate as a precursor simultaneously is capable of inducing synthesis of curcuminoid of temulawak curcuminoid.

\section{CONCLUSION}

Based on the results. the conclusion that may be drawn are the addition of Phenylalanin and Sodium Acetate with various concentrations in a common medium MS were capable to induce the synthesis of curcuminoid in a temulawak callus. The addition of Phenylalanin as much as $4 \mathrm{mg} / \mathrm{l}$ into growing media was capable to induce the production of curcumin as many as $0.8861 \%$ and desmethoxycurcumin $0.3307 \%$ while the addition of Sodium Acetate $2 \mathrm{mg} / \mathrm{l}$ into growing media produce curcumin levels as many as $0.7514 \%$ and desmethoxycurcumin $0.3898 \%$. Phenylalanin impact on the synthesis of curcumin. meanwhile Sodium Acetate impact on the synthesis of desmethoxycurcumin.

\section{ACKNOWLEDGMENT}

The authors thank Nina Artanti. PhD for her support and collaboration.
REFERENCES

Afifah E. 2003. Khasiat dan Manfaat Temulawak: Rimpang Penyembuh Aneka Penyakit. Jakarta (ID): Agro Media Pustaka. HIm. 7-13.

Cahyono B. 1998. Tembakau Budidaya dan Analisis Usaha Tani. Yogyakarta(ID): Kanisius.

Dalimartha S. 2000. Atlas Tumbuhan Obat Indonesia. Jilid II. Jakarta (ID): Trubus Agri Widya. HIm 182186.

Hendaryono DPS, Wijayani A. 1994. Teknik Kultur Jaringan. Kanisius. Yogyakarta.

Indrayanto G, Rahman A. 1990. Prospek Bioteknologi Sel Tanaman untuk Produksi Bahan Obat Nabati secara in vitro. Medika Jurnal Kedokteran dan Farmasi. Jakarta.

Indrayanto G. 1987. Produksi Metabolit Sekunder dengan Teknik Kultur Jaringan Tanaman. Seminar Nasional. Metabolit Sekunder. Yogyakarta (ID): Universitas Gadjah Mada.

Rukmana R. 1995. Temulawak. Tanaman Rempah dan Obat. Yogyakarta (ID): Kanisius.

Street HE. 1977. Recent Advence in The Production of Medical Substances by Plant Cell Culture. New York. 3-6.

Tomes DT. Ellis BE. Harney PM. Kasha KS. Petenson RL. 1982. Aplication of Plant Cell and Tissue Culture to Agriculture and Industry. Guleph (CA): The University of Guleph.

Tonnesen HH. 1986. Chemistry. Stability and Analysis of Curcumin. Oslo (NO): Institute of Pharmacy University of Oslo.

Untung S, Fatimah N. 2003. Kultur Jaringan Tanaman. Malang (ID): Universitas Muhammadiyah Malang.

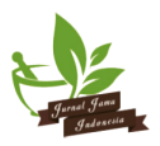

